\title{
The Relationship Between University Rankings And Outcomes Measurement
}

Chuanfu Ding, (peter96060@gmail.com), University of Hawaii at Hilo

Terrance Jalbert, (jalbert@hawaii.edu), University of Hawaii at Hilo

Steven P. Landry, (steve.landry@miis.edu), Monterey Institute of International Studies

\begin{abstract}
This paper examines the relationship between university ranks and outcome measurements. Many students select the university that they will attend based on these rankings In this paper the rankings conducted by two studies are examined. U.S. News and World Report rankings are based upon measures of the quality of input, retention while in school and other measures. A new group of rankings are based on the output performance of universities. Jalbert, Rao and Jalbert (2002) rank schools based on the extent to which the school places its graduates in top CEO positions and the salary that they receive when in these positions. In an optimal world, input rankings should correspond with output rankings. This paper examines the extent to which these rankings track each other and the sensitivity of rankings to changes in methodology utilized.
\end{abstract}

\section{INTRODUCTION}

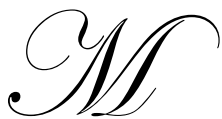

edia ranking of universities provide a reference for students and parents in deciding which university to attend. Evidence on the importance of these rankings is mixed. McNeal (2004) argues that rankings do help students narrow the many choices that have available to them. However, Hossler and Foley (1995) find that university rankings have a small impact on the choice of university. Webster (1992) argues that although rankings published in magazines have their limitations, they provide more useful information than alternative sources of information such as accrediting agencies and most college guides. McDonough Antonio, Walpole and Perez (1998) examine who use these rankings and the types of freshman students most likely to find rankings useful in making a selection. Others argue that what the rankings really measure is the shape and preferences of the higher education market (Best in show, 2003). Some articles contend that rankings cause problems by introducing competition between universities and thwarting cooperation (Ehrenberg, 2003). Yet others argue that rankings have resulted in the creation of more elite schools than were present in earlier times (Samuelson, 2005). Certainly, an inappropriate "bad" ranking can have a significant negative economic impact on a university. Similarly an inappropriate "positive" rating can lead students to enroll in a suboptimal school. Although the evidence regarding the extent to which school rankings accurately reflect the quality of education are mixed, many schools have reallocated resources to actively enhance their rankings. Machung (1998) finds that colleges use rankings to attract students, to bring in alumni donations, to recruit faculty and administrators, and to attract potential donors.

A number of major news publications publish rankings of the best universities in United States each year. Each of the publications utilize unique methodologies and sources of data to create their version of the best national or regional universities in the United States. These rankings are generally based on input measures, such as the average SAT of accepted students and student retention. In recent years, a great deal of attention has been focused on measuring the output of universities. The Association to Advance Collegiate Schools of Business (AACSB) places a great deal of emphasis on outcome based measurements to determine the performance of business schools. One such outcome based study conducted by Jalbert, Rao and Jalbert (JRJ) (2002) ranks universities based on the extent to which the universities place their graduates in top CEO positions and the salary that they receive in these positions. Optimally, rankings based on inputs should closely mirror rankings based on outcomes. 
Of interest in this study is the extent to which input and output based rankings track each other and an analysis of how changes in methodology can improve the correlation of input and output rankings. Specifically, this study explores the methodologies utilized by U.S. News and World Report's America's Best Colleges, an input based ranking, and JRJs outcome performance measurement. The current research is not intended as a criticism of these previous studies. To the contrary, these previous studies are important and well done research that can help students and their parents make better decisions. Indeed, the importance of these school rankings has increased substantially in recent years as schools become more competitive. The intent of this study is to extend this line of research by demonstrating the difficulties and choices associated with the rankings, and the sensitivity of the final ranking to the methodologies employed. In the following section the literature is discussed. Next, the methods used to aggregate the data are examined. The analysis continues by demonstrating how changing variables affects the final outcome and computing the impact of each variable on the final rankings. Finally some concluding comments are provided.

\section{PRIOR LITERATURE}

There is no shortage of discussion about the merits of the various university rankings. Gourman (1997, 1998), rank graduate and professional programs in more than 100 academic areas. Hattendory-Westney (1998) rank over 3,600 universities on a range of perspectives including, admission selectivity, publication by faculty, faculty salaries and other areas. Gater (1995) ranks universities based on their research and development. While many rankings limit themselves to U.S. schools Times Higher Education Supplement ranks the top 200 universities throughout the world based on publication, student to faculty ratio and a survey of faculty. Perhaps the most popular ranking is produced by the US News and World Report magazine. USNWR ranks universities by subject area and provides an overall ranking.

A myriad of articles have been written that analyze the methodologies of these rankings (see Kersten, 2000, The Learning Alliance for Higher Education, 2003, and Thompson 2003). Goldstein and Spiegelhalter (1996) discuss the statistical properties of ranking systems and suggest that caution is warranted in interpreting ranking differences. Baugham and Goldman (1999) and Trieschmann et al. (2000) examine the extent to which college rankings and faculty publications are related. A number of articles express concern regarding the methodologies utilized by USNWR (see Mallete, 1995, and Clark, 2004, Wright 1992). Clarke (2004) criticizes the methodologies used by USNW rankings on two fronts. First, that the weighting of factors used to compute the index is arbitrary and that the way the scores are reported leads to a false sense of precision. The authors suggest that the USNWR rankings might be improved by changing the weighting system and doing away with a single overall weighting score.

Another line of literature explores the reactions of universities to rankings. Citing flaws in the ranking systems, some universities refuse to provide information to ratings agency. Other universities debate whether they should publicize the rankings Staroba (1997). Still others debate if the university should change their practices to improve their ratings Jennings (2004). Machung (1998) argues that while leaders in academia criticize annual rankings, their institutions utilize the rankings to promote themselves. Meredith (2004) notes that admissions outcomes are affected by USNWR ranking changes and that rankings affect public and private schools differently.

\section{DATA AND METHODOLOGY}

Data for this study were obtained from two sources. Output rank data were obtained from JRJ (2002). While JRJ, 2002 rank a large number of universities, they published only the top 50 ranked schools in their article. Data regarding the rankings of additional schools were obtained for this study from Mercedes Jalbert. The rankings are based on Forbes Compensation Survey data spanning a ten year period and including 8,000 observations. JRJ (2002) provides two rankings that are of interest in this study. The first ranking is of the universities that granted degrees to individuals that are CEO's of major U.S. corporations. The schools are ranked by the number of CEO's that hold a degree from their school. Those schools that are responsible for educating more CEO's are ranked higher. The second ranking is the salaries earned by CEO's relative to the university where they earned their degrees. Schools whose graduates earn higher salaries as the CEO are ranked higher. To control for a single graduate exerting an undo influence on the rankings, only schools that produced two or more CEO's, were considered for the salary ranking. In 
order to control for inflation effects, compensation data was deflated using the Consumer Price Index to 1996 equivalent dollars. One hundred fifty eight institutions were ranked based on their graduates' average compensation.

Data on input rankings were obtained from USNWR. USNWR published its first college ranking in 1983. Since then the rankings have been refined to include more variables in its complex methodology. USNWR first divides the institutions into categories by mission or regions. The categories are: national university, national liberal arts colleges, regional universities, and regional liberal arts colleges. Separate rankings are provided for each of these categories. For the purpose of this study, only the national university categories are examined. Table 1 outlines 15 independent data items that USNWR currently assembles from various data sources to create their rankings. As noted above, a number of studies have examined the variables used by USNWR including Porter (2000) and Gater (2002). They argue that alternative measures might be utilized to improve the rankings. The Learning Alliance for Higher Education argues that the UWNW rankings formula can be closely approximated by using only two factors, graduation rate and peer review score.

The fifteen data items used by USNWR are first combined into seven variables: academic reputation, retention, faculty resources, student selectivity, financial resources, value added and alumni giving rate. Finally, these seven variables are aggregated into a single score. This aggregated score is scaled against the top score, and then expressed as a percentage of the top score. The aggregation process USNWR uses is a "pooling of public opinion" approach to determining what the ranking factors and their relative weightings are in determining the final ranking (Shale and Liu, 2002). Finally, the colleges in each category are ranked against their peers, based on their overall weighted score.

Table 1 indicates the factors and weightings used by usnwr to develop their rankings.

Table 1: USNWR Factors And Weightings

\begin{tabular}{|c|c|c|c|}
\hline Ranking Indicators & Overall Weight & Sub indicators & Sub-indicators weight \\
\hline Academic Reputation & $25 \%$ & Academic reputation survey & $25 \%$ \\
\hline \multirow[t]{2}{*}{ Graduation and Retention } & \multirow[t]{2}{*}{$20 \%$} & Six-year graduation rate & $80 \%$ \\
\hline & & Freshman retention rate & $20 \%$ \\
\hline \multirow[t]{6}{*}{ Faculty Resources } & \multirow[t]{6}{*}{$20 \%$} & Classes fewer than 20 students & $30 \%$ \\
\hline & & Classes with $50+$ students & $10 \%$ \\
\hline & & Average faculty salary & $35 \%$ \\
\hline & & Professors with top degree in their fields & $15 \%$ \\
\hline & & Student faculty ratio & $5 \%$ \\
\hline & & Proportion of full time faculty & $5 \%$ \\
\hline \multirow[t]{4}{*}{ Student Selectivity } & \multirow[t]{4}{*}{$15 \%$} & SAT/ACT score & $40 \%$ \\
\hline & & $\begin{array}{l}\text { Yield the proportion of those accepted who } \\
\text { attend }\end{array}$ & $10 \%$ \\
\hline & & Acceptance rate & $15 \%$ \\
\hline & & High school class standing-top $10 \%$ & $35 \%$ \\
\hline \multirow[t]{2}{*}{ Financial Resources } & \multirow[t]{2}{*}{$10 \%$} & $\begin{array}{c}\text { Educational expenditures } \\
\end{array}$ & $80 \%$ \\
\hline & & Other expenditures & $20 \%$ \\
\hline Alumni Giving & $5 \%$ & Average alumni giving rate & $100 \%$ \\
\hline Value Added & $5 \%$ & Graduation rate performance & $100 \%$ \\
\hline Total & $100 \%$ & --------------------------------------- & $100 \%$ \\
\hline
\end{tabular}

USNWR rankings have been refined over time. In the past, USNWR's ranking model put less emphasis on input measures, such as the average high school class rank of a college's entering freshmen and the range of their standardized test scores. Currently, the model puts more emphasis on the performance of students while in school, such as the percentage of a college's entering class that returns for a second year. The final score of each ranked school is rounded to the nearest whole number, which creates more ties in the rankings. (In the past, the score was carried to one place after the decimal point.) U.S. News made this change because small statistical differences among 
institutions are not significant in setting them apart. Also, a school's score in the reputation survey is now shown on a scale from 4.0 (the highest) to 1.0 (the lowest). In the past, each school's reputation rank was displayed, such as 164th. Thompson and Morse (1997) argue that showing the actual score is a more direct way of presenting the same information.

To arrive at the final rankings for each school, USNWR first calculates a score for each attribute: reputation, retention, faculty resources, selectivity, financial resources, value added, and alumni giving. According to Doug Shale and Yolanda Liu's study (2002), a matrix of data is created with the mean values and corresponding standard deviations for each indicator over all colleges. Next, each raw score for each indicator and each college is converted to a z-score by subtracting the particular raw score from the mean score calculated for the corresponding indicator and dividing by the standard deviation calculated for that indicator. Then, the $\mathrm{z}$ scores for each indicator are rescaled to non negative values. The weight of each indicator is applied to the rescaled $\mathrm{z}$ score. The overall score is the summation of all rescaled z score multiplied by its associated weights. Finally, schools with the highest value for each component of an attribute are assigned a score of 100 percent. Every other school's value is then taken as a percentage of the top value. Resulting scores are weighted and totaled for the attribute scores.

\section{TEST PROCEDURES AND RESULTS}

In this section the relationship between USNWR university ranks and JRJ (2002) outcomes measurement are examined empirically. To complete the analysis, the top 50 national universities ranked by USWNR were matched to the institution's ranking of both JRJs educational ranking and compensation rankings. The results are presented in Columns, 3, 5, and 7 of Table 2. Among the USWNR 50 best national universities, forty five institutions could be matched with JRJ's educational background by school ranking, five institutions could not be matched. Thirty-six USNW institutions were matched with JRJ's compensation level ranking. The remaining fourteen could not be matched. The differences in ranks between the ranking systems are quite dramatic. For example, Boston College ranked thirty eight by USNWR. However, its associated ranking in Jalbert 2003 was ninety-seven for education and 135 for compensation.

Those USNW observations that were not matched to the JRJ (2002) rankings, were excluded from further consideration in the analysis. Because of this elimination process, the original rankings were no longer continuous. To recreate a continuous ranking system, the observations that remained after elimination were re-ranked. The revised rankings run from one to forty five for the educational ranking series and one to thirty-six for the compensation ranking series. These revised rankings are presented in columns 4,6 , and 8.

The primary purpose of this study is to exam the extent to which input rankings are correlated with output rankings. To begin the comparison of these rankings the correlation between the series are computed. The correlation scores between USWNR and Jalbert are presented in Table 3. By observing the magnitude of correlation coefficients, a clear difference between the two series can be seen. The correlations range between 0.335 and 0.169 . These low correlations indicate that there is room to improve the relationship between input and output measures.

Table 2 shows lists universities ranked by USNWR and two JRJ rankings. In addition, the table shows the re-ranked scores of only those universities that were contained in both USNWR and JRJ. The first column is the observation number and the second column is the University name. The third column is the original USNWR ranking. The fourth column re-ranks those universities from USNWR that could be matched with the JRJ Education

Ranking. The fifth and sixth columns are the JRJ education ranking and re-ranking of matched observations. The seventh and eigth columns are the JRJ compensation and re-ranking of matched observations. 
Table 2: Rankings And Adjusted Rankings

\begin{tabular}{|c|c|c|c|c|c|c|c|}
\hline Observation & School & USNWR & $\begin{array}{c}\text { Re-ranked } \\
\text { USNWR }\end{array}$ & Education & $\begin{array}{l}\text { Re-ranked } \\
\text { Education }\end{array}$ & Comp. & $\begin{array}{c}\text { Re-ranked } \\
\text { Comp. }\end{array}$ \\
\hline 1 & Boston College & 38 & 36 & 97 & 32 & 135 & 35 \\
\hline 2 & Brown & 9 & 9 & 50 & 26 & 18 & 4 \\
\hline 3 & Carnegie Mellon & 23 & 23 & 70 & 29 & 89 & 24 \\
\hline 4 & Case Western Reserve & 37 & 35 & 79 & 30 & 123 & 33 \\
\hline 5 & Columbia & 9 & 9 & 21 & 17 & 128 & 34 \\
\hline 6 & Cornell & 14 & 14 & 4 & 4 & 11 & 2 \\
\hline 7 & Dartmouth & 7 & 7 & 12 & 11 & 50 & 17 \\
\hline 8 & Duke & 3 & 3 & 44 & 25 & 64 & 20 \\
\hline 9 & Georgetown & 21 & 21 & 88 & 31 & 57 & 18 \\
\hline 10 & Georgia Inst of Tech & 41 & 39 & 18 & 15 & 67 & 21 \\
\hline 11 & Harvard & 1 & 1 & 3 & 3 & 91 & 25 \\
\hline 12 & Johns Hopkins & 14 & 14 & 120 & 36 & 41 & 13 \\
\hline 13 & Lehigh & 34 & 32 & 40 & 23 & 34 & 10 \\
\hline 14 & MIT & 6 & 6 & 11 & 10 & 63 & 19 \\
\hline 15 & New York University & 34 & 32 & 14 & 13 & 40 & 12 \\
\hline 16 & Northwestern & 9 & 9 & 10 & 9 & 33 & 9 \\
\hline 17 & Pennsylvania State & 45 & 41 & 41 & 24 & 98 & 28 \\
\hline 18 & Princeton & 1 & 1 & 1 & 1 & 45 & 15 \\
\hline 19 & Rice & 17 & 17 & 65 & 27 & 141 & 36 \\
\hline 20 & Stanford & 5 & 5 & 7 & 7 & 43 & 14 \\
\hline 21 & Syracuse & 40 & 38 & 115 & 35 & 13 & 3 \\
\hline 22 & Tufts & 23 & 23 & 110 & 34 & 111 & 31 \\
\hline 23 & $\begin{array}{l}\text { Illinois-Urbana- } \\
\text { Champaign }\end{array}$ & 45 & 41 & 27 & 20 & 30 & 8 \\
\hline 24 & Berkeley & 23 & 23 & 25 & 19 & 85 & 23 \\
\hline 25 & UCLA & 28 & 28 & 68 & 28 & 101 & 30 \\
\hline 26 & Chicago & 14 & 14 & 98 & 33 & 8 & 1 \\
\hline 27 & Michigan & 23 & 23 & 6 & 6 & 82 & 22 \\
\hline 28 & $\begin{array}{l}\text { North Carolina-Chapel } \\
\text { Hill }\end{array}$ & 27 & 27 & 8 & 8 & 97 & 27 \\
\hline 29 & Notre Dame & 19 & 19 & 15 & 14 & 93 & 26 \\
\hline 30 & Pennsylvania & 7 & 7 & 5 & 5 & 28 & 7 \\
\hline 31 & USC & 41 & 39 & 37 & 22 & 26 & 6 \\
\hline 32 & Virginia & 21 & 21 & 34 & 21 & 114 & 32 \\
\hline 33 & Wisconsin-Madison & 38 & 36 & 13 & 12 & 99 & 29 \\
\hline 34 & Vanderbilt & 19 & 19 & 20 & 16 & 19 & 5 \\
\hline 35 & Wake Forest & 28 & 28 & 130 & 38 & 48 & 16 \\
\hline 36 & Yale & 3 & 3 & 2 & 2 & 35 & 11 \\
\hline 37 & Cal Inst of Technology & 9 & 9 & 275 & 42 & & \\
\hline 38 & Washington University & 17 & 17 & 22 & 18 & & \\
\hline 39 & Worcester Polytechnic & 48 & 44 & 123 & 37 & & \\
\hline 40 & Rochester & 31 & 30 & 286 & 43 & & \\
\hline 41 & UC-Santa Barbara & 47 & 43 & 358 & 45 & & \\
\hline 42 & William and Mary & 32 & 31 & 294 & 44 & & \\
\hline 43 & Tulane & 34 & 32 & 217 & 41 & & \\
\hline 44 & Rensselaer Polytechnic & 48 & 44 & 141 & 39 & & \\
\hline 45 & Emory & 9 & 9 & 170 & 40 & & \\
\hline 46 & Brandies & 28 & & & & & \\
\hline 47 & UC-Davis & 41 & & & & & \\
\hline 48 & UC-Irvine & 41 & & & & & \\
\hline 49 & UC-San Diego & 33 & & & & & \\
\hline 50 & Yeshiva & 48 & & & & & \\
\hline
\end{tabular}


This table reports correlation coefficients between usnwr rankingsAnd two jrj rankings based on education and compensation.

Table 3: Correlation Between Rankings

\begin{tabular}{|c|c|c|c|c|c|c|}
\hline & USNWR & $\begin{array}{c}\text { Re-ranked } \\
\text { USNWR }\end{array}$ & Education & $\begin{array}{c}\text { Re-ranked } \\
\text { Education }\end{array}$ & Comp. & $\begin{array}{c}\text { Re-ranked } \\
\text { Comp. }\end{array}$ \\
\hline USNWR & 1 & & & & & \\
\hline Re-ranked USNWR & 0.9986 & 1 & & & & \\
\hline Education & 0.3366 & 0.3352 & 1 & & & \\
\hline Re-ranked education & 0.4637 & 0.4682 & 0.8601 & 1 & & \\
\hline Comp. & 0.1691 & 0.1807 & 0.0942 & 0.1544 & 1 & \\
\hline Re-ranked Comp. & 0.1503 & 0.1617 & 0.0828 & 0.1377 & 0.9899 & 1 \\
\hline
\end{tabular}

In order to analyze the sources of these correlations and the extent to which changing methodologies alters the correlations, it is necessary to re-compute the USNWR from the raw data. The difficulty associated with this procedure is that the entire dataset used by USNWR to create the rankings are not published by USNWR and as such, were not available to the authors. Because of this limitation, the rankings were recreated based on the information that was available. Raw scores for the academic reputation, student selectivity, faculty resources, and financial resources are not made available by USWNR. However, the overall weight each variable contributes to the final ranking for academic reputation are known to be 25 percent, student selectivity $15 \%$, faculty resources $20 \%$, and financial resources $10 \%$. While raw data was not available, each university's ranking associated with the indicator is published. Using the available data, we re-computed scores for the sub indicators. By assigning the corresponding scores to the indicator ranking, the values for the missing indicators subject to the overall ranking published by USNWR are estimated.

According to Doug Shale and Yolanda Liu (2002), USNWR does not reference the normal distribution. Instead the z-scores are rescaled by subtracting the smallest $\mathrm{z}$-score value from all the z-score values for the given indicator. Then, the rescaled positive z-scores are multiplied by the weight assigned for the particular indicator. The totals of weighted z-scores are normalized by dividing the largest total into each of the overall totals, so the highest scoring institution is awarded a normalized score of 100 . To re-compute the rankings, the mean and standard deviation for each raw score, for each indicator, are computed. Then, each raw score was converted into a z-score. The z-score is calculated by subtracting the raw score's mean and dividing it by the standard deviation. The replicated ranking results are presented in Table 4 . The results of our replicated ranking have a small degree of difference with the original ranking published by USNWR.

Next, we examine the accuracy of the estimation process by examining the correlations between scores. The results are presented in Table 5. The original USNWR rankings have a correlation score of 0.98 with our recomputed ranking. In an attempt to improve the correlation between the estimated rankings and the original USNWR rankings, we recomputed the re-ranked score based on the overall score relative to the recomputed score. The re-ranked rankings have a correlation of 0.97. Thus the process of re-ranking reduced the correlation between our estimated score and the original USNWR score. As a result, the remainder of the analysis is completed based on the recomputed scores.

\section{CORRELATION MAXIMIZATION}

The next step of our study was to maximize the correlation score between the JRJ rankings and USNWR's ranking by changing the weights of the USNWR ranking indicators. Frontline's Premium Solver program was used to calculate the maximum possible correlation between Jalbert and USNWR ranking by changing the weight of USNWR ranking indicators. By adjusting the weights of the USNWR an average increase in correlation score of 0.2 was achieved. The weightings that produced these maximum correlations are reported in Table 6. 
Table 4 reports the replicated rankings of USNWR. In the first two columns, the original USNWR ranking (USNW rank) and USNWR overall scores (USNW Score) are reported. The third and fourth columns report the recomputed rank (Rec Rank) and score (Rec. sank score).

Table 4: Recomputed USNW Ranking

\begin{tabular}{|c|c|c|c|c|c|c|c|c|c|}
\hline School Name & $\begin{array}{c}\text { USNW } \\
\text { rank }\end{array}$ & $\begin{array}{c}\text { USNW } \\
\text { Score }\end{array}$ & $\begin{array}{l}\text { Rec } \\
\text { rank }\end{array}$ & $\begin{array}{l}\text { Rec. } \\
\text { rank } \\
\text { score }\end{array}$ & School Name & $\begin{array}{c}\text { USNW } \\
\text { rank }\end{array}$ & $\begin{array}{c}\text { USNW } \\
\text { Score }\end{array}$ & $\begin{array}{c}\text { Rec } \\
\text { rank }\end{array}$ & $\begin{array}{l}\text { Rec. } \\
\text { rank } \\
\text { score }\end{array}$ \\
\hline Harvard & 1 & 100 & 2 & 3.7356 & Mich-Ann Arbor & 23 & 88 & 23 & 2.7718 \\
\hline Princeton & 1 & 100 & 1 & 3.7952 & $\begin{array}{c}\text { North Carolina- } \\
\text { CH }\end{array}$ & 27 & 87 & 27 & 2.5590 \\
\hline Duke & 3 & 99 & 5 & 3.4997 & Brandeis & 28 & 85 & 29 & 2.2988 \\
\hline Yale & 3 & 99 & 3 & 3.6382 & UCLA & 28 & 85 & 33 & 2.1122 \\
\hline Stanford & 5 & 98 & 4 & 3.5730 & Wake Forest & 28 & 85 & 28 & 2.3945 \\
\hline MIT & 6 & 97 & 6 & 3.4749 & Rochester & 31 & 84 & 30 & 2.2695 \\
\hline Dartmouth & 7 & 96 & 7 & 3.3615 & $\begin{array}{c}\text { William and } \\
\text { Mary }\end{array}$ & 32 & 82 & 31 & 2.2144 \\
\hline Pennsylvania & 7 & 96 & 8 & 3.3335 & UC-San Diego & 33 & 81 & 32 & 2.2013 \\
\hline Brown & 9 & 95 & 9 & 3.2845 & Lehigh & 34 & 80 & 35 & 2.0566 \\
\hline Cal. Inst of Tech. & 9 & 95 & 10 & 3.2337 & NYU & 34 & 80 & 34 & 2.1066 \\
\hline Columbia & 9 & 95 & 12 & 3.2044 & Tulane & 34 & 80 & 39 & 1.8755 \\
\hline Emory & 9 & 95 & 16 & 3.0825 & Case Western R. & 37 & 79 & 36 & 1.9743 \\
\hline Northwestern & 9 & 95 & 11 & 3.2299 & Boston College & 38 & 78 & 37 & 1.8970 \\
\hline Cornell & 14 & 94 & 15 & 3.1325 & Wisconsin-Mad. & 38 & 78 & 38 & 1.8876 \\
\hline Johns Hopkins & 14 & 94 & 13 & 3.1976 & Syracuse & 40 & 76 & 48 & 1.5367 \\
\hline Chicago & 14 & 94 & 17 & 3.0698 & Georgia Tech & 41 & 75 & 41 & 1.6801 \\
\hline Rice & 17 & 93 & 14 & 3.1686 & UC-Davis & 41 & 75 & 43 & 1.6635 \\
\hline Washington Univ. & 17 & 93 & 18 & 2.9367 & UC-Irvine & 41 & 75 & 42 & 1.6673 \\
\hline Notre Dame & 19 & 91 & 19 & 2.9078 & USC & 41 & 75 & 44 & 1.6561 \\
\hline Vanderbilt & 19 & 91 & 24 & 2.7516 & Penn State & 45 & 74 & 45 & 1.6097 \\
\hline Georgetown & 21 & 90 & 22 & 2.7884 & Illinois-UC & 45 & 74 & 40 & 1.7282 \\
\hline Virginia & 21 & 90 & 20 & 2.9008 & $\begin{array}{c}\text { UC-Santa } \\
\text { Barbara }\end{array}$ & 47 & 72 & 46 & 1.6074 \\
\hline Carnegie Mellon & 23 & 88 & 26 & 2.5771 & Rensselaer Poly. & 48 & 71 & 50 & 1.4137 \\
\hline Tufts & 23 & 88 & 25 & 2.6022 & Worcester Poly. & 48 & 71 & 47 & 1.5636 \\
\hline Berkeley & 23 & 88 & 21 & 2.8318 & Yeshiva & 48 & 71 & 49 & 1.4261 \\
\hline
\end{tabular}

Table 5 shows the correlation between the original USNWR rankings and the estimated scores as computed in this paper.

Table 5: The Correlation Of Recomputed USNWR Ranking

\begin{tabular}{|c|c|c|c|}
\hline & Original USNWR & $\begin{array}{c}\text { Re-computed Re-ranked } \\
\text { USNWR }\end{array}$ & Re-computed USNWR \\
\hline Original USNWR & 1 & & \\
\hline Re-computed Re-ranked USNWR & 0.974356972 & 1 & 1 \\
\hline Re-computed USNWR & 0.98720954 & 0.988955582 & \\
\hline
\end{tabular}


Table 6 shows the maximum correlations that are achieved by changing the weightings on the USNWR rank computations. The change in correlation achieved by changing the USNWR weightings are also reported.

Table 6: Correlation Maximized By Solver

\begin{tabular}{|c|c|c|c|}
\hline & Original & Solver & Change \\
\hline Edu. Vs. Recomp. USNWR & 0.325803907 & 0.553392761 & +0.227588854 \\
\hline Reranked Edu. Vs Recomp. USNWR & 0.468197551 & 0.68756155 & +0.219363999 \\
\hline Reranked Comp. Vs Recomp. USNWR & 0.121981894 & 0.310911415 & +0.188929521 \\
\hline Comp Vs Recomp. USNWR & 0.141469525 & 0.331485266 & +0.190015741 \\
\hline \multicolumn{2}{|l}{} & Max Change & +0.227588854 \\
\cline { 2 - 4 } & & Mean Change & +0.206474529 \\
\hline
\end{tabular}

Table 7 shows the weights that maximized the correlation between Jablert and USNWR. Notice that the suggested weights involve eliminating graduation and student selectivity altogether from the ranking scheme. This result holds for both the education and compensation analysis. The education analysis suggests eliminating faculty resources as a criteria, however; the compensation analysis suggests increasing the weight of this indicator. Similarly, the compensation analysis suggests eliminating academic reputation as a indicator, but the education analysis suggests increasing the weight of this indicator. The results differ considerably depending upon the use of the raw rankings or the re-ranked series. For example, the analysis using re-ranked compensation suggests that faculty resources comprise more than half of the weightings for all indicators. However, the raw rankings suggest a weighting of less than 22 percent for this indicator.

Table 7 shows the USNWR factor weightings that produced the largest correlation between USNWR rankings and JRJ rankings.

Table 7 Solver Suggested Weights

\begin{tabular}{|c|c|c|c|c|c|}
\hline Ranking Indicators & $\begin{array}{c}\text { USNWR } \\
\text { Weightings }\end{array}$ & $\begin{array}{c}\text { Edu. Vs. } \\
\text { Recomp. } \\
\text { USNWR }\end{array}$ & $\begin{array}{c}\text { Reranked Edu. } \\
\text { Vs Recomp. } \\
\text { USNWR }\end{array}$ & $\begin{array}{c}\text { Reranked Comp. } \\
\text { Vs Recomp. } \\
\text { USNWR }\end{array}$ & $\begin{array}{c}\text { Comp Vs } \\
\text { Recomp. } \\
\text { USNWR }\end{array}$ \\
\hline Academic Reputation & .25 & 0.47409 & 0.5667 & 0 & 0 \\
\hline Graduation and Retention & .20 & 0 & 0 & 0 & 0 \\
\hline Faculty Resources & .20 & 0 & 0 & 0 & 0.2192 \\
\hline Student Selectivity & .15 & 0 & 0.0141 & 0.3702 & 0 \\
\hline Financial Resources & .10 & 0.0545 & 0.2596 & 0 & 0.2068 \\
\hline Alumni Giving & .05 & 0.2938 & 0.1596 & 0.0982 & 0 \\
\hline Value Added & .05 & 0.1776 & 1 & & 1 \\
\hline Total & & 1 & & & \\
\hline
\end{tabular}

\section{CONCLUDING COMMENTS}

The US News and World Report ranking measures the quality of universities based on seven categories. The USNWR categories are related to measures of input, such as the SAT scores of incoming students and retention rates. On the other hand, Jalbert, Rao and Jalbert (2002) provide two rankings that measure the output of universities. The first ranking is the number of individuals the University places in top CEO positions. The second ranking is the salary that its graduates command in those high-ranking positions. The evidence indicates that the two rankings are not closely related. In an optimal world input rankings, should correspond to output rankings. This paper studies the extent to which this relationship holds for two such rankings. The paper begins by computing the correlation between the two rankings. Next, it suggests alternate weightings for the input measure so that it more closely corresponds to a relevant measure of output. 
This study has three primary limitations. First, USNWR does not provide the full reporting of data that it uses to compute the rankings. Thus, it is necessary to estimate the USNWR methodology in this paper. Should USNWR provide a full listing of its underlying data in the future, additional precision and insights might be gained. Second, this study examines only how the USNWR rankings correspond to one set of output rankings. Completing similar analysis on other measures of the quality of university outcomes would provide additional insights. Third, the Jalbert rankings examine only those individuals that are exceptionally successful as CEO's., while universities educate individuals for many roles. Additional output measures might include success a variety of other fields that reflect the mission of the University. Despite these limitations, this paper represents and important step in analyzing how rankings are conducted and improving the relationship between input and output measures.

\section{REFERENCES}

1. Baughman, James C. and Robert N. Goldman. College Rankings and Faculty Publications: Are They Related? Change v31 n2 (March/April 1999): p.44-51.

2. $\quad$ Best in Show: Rethinking the Rankings Game. Change, September/October 2003, p. 55.

3. Clarke, Marguerite. Weighing Things Up: A Closer Look at the U.S. News and World Report's Ranking Formulas. College and University Journal. v79 n3 (Winter 2004): p. 3-9.

4. $\quad$ Ehrenberg, Ronald G. Reaching for the Brass Ring: The U.S. News and World Report Rankings and Report. The Review of Higher Education, 26 (2) (Winter 2003): p. 145-162. The United .

5. Gater, Denise S. A Review of Measures Used in U.S. News \& World Report's America's Best Colleges. Gainesville, FL: Lombardi Program on Measuring University Performance, Univ. of FL, 2002.

6. Gater, Denise S. The Top American Research Universities National Research Council (U.S.) Committee for the Study of Research-Doctorate Programs in the United States. Research-doctorate programs in the United States : continuity and change. Washington, D.C. : National Academy Press, 1995.

7. Goldstein H. and DJ Spiegelhalter. League Tables and Their Limitations: Statistical Issues in Comparisons of Institutional Performance. Journal of the Royal Statistical Society Series A: Statistics in Society. 159(Part 3)(1996): p.385-409.

8. $\quad$ Gourman, Jack. Gourman Report: Graduate Programs (8th Ed.). NY: Princeton Review Publishing, 1997.

9. Gourman, Jack. Gourman Report: Undergraduate Programs (10th Ed.). NY: Princeton Review Publishing, 1998.

10. Hattendorf-Westney, Lynn C. Educational Rankings Annual. Detroit: Gale Research Inc., 1998.

11. Hossler, Don and Erin M. Foley. Reducing the Noise in the College Choice Process: The Use of College Guidebooks and Ratings. New Directions for Institutional Research. n88 (Winter 1995): p.21-30.

12. Jalbert, Terrance, Ramesh Rao, and Mercedes Jalbert (2002) Does School Matter? An Empirical Analysis of CEO Education, Compensation and Firm Performance, International Business and Economics Research Journal, Vol. 1(1) Winter, p. 83-98.

13. Jennings, Matthew V. A Thin Line Between Love and Hate. Currents, v30 n9 (October 2004): 22-27.

14. Kersten, Glenn. Grading on the Curve: College Ratings and Rankings. Points of Reference. January 2000, http://www.sls.lib.il.us/reference/por/features/99/collrank.html.

15. $\quad$ Machung, A. (1998). Playing the rankings game. Change, 30 (4), 12-16. EJ 568897.

16. Mallette, Bruce I. Money Magazine, U.S. News and World Report, and Steve Martin: What Do They Have in Common? New Directions for Institutional Research. n88 (Winter 1995): p.31-44.

17. McDonough, Patricia M., Anthony Lising Antonio, MaryBeth Walpole, and Leonor Xochitl Perez. College Rankings: Democratized College Knowledge for Whom? Research in Higher Education. v39, n5 (October, 1998): p.513-537.

18. McNeal, Cornelia H. Who Says They Matter? Currents, v30 n9 (October 2004): 28-30.

19. Machung, Anne. Playing the Rankings Game. Change. v30 n4 (July/August 1998): p.12-16.

20. Meredith, Marc. Why Do Universities Compete in the Ratings Game? An Empirical Analysis of the Effects of the U.S. News and World Report College Rankings Research in Higher Education, v45 n5 (August 2004): 443-461.

21. Porter, Stephen. The Robustness of the Graduation Rate Performance Indicator Used in the U.S. News \& World Report College Rankings. The CASE International Journal of Educational Advancement. v1 n2: p.145-164 (2000). 
22. Samuelson, Robert J. In Praise of Rankings. Newsweek/Kaplan's How To Get Into College (Alternate title: America's Hottest Colleges). 2005 edition.

23. Shale, Doug and Yolanda Liu Ranking the Rankers of Universities: Canada’s Maclean's Magazine Vs. U.S. News \& World Report. Association for Institutional Research. June 2002.

24. Staroba, K. The Rankings Ruckus: PR Pros Talk about How -- and How Not -- to Publicize College Rankings. Currents. v23 n6 (1997): p.30.

25. The Learning Alliance for Higher Education. Best in Show: Rethinking the Rankings Game. Change. v35 n5 (September/October 2003): p. 55-58.

26. Thompson, Nicholas. The Best, The Top, The Most. New York Times (August 3, 2003) 4A:24.

27. Thompson, J.J. and Morse, Robert J. An explanation of the U.S. News rankings. U.S News \& World Report 09/01/97, Vol. 123 Issue 8, p98.

28. Trieschmann, J.S. et al. Serving Multiple Constituencies in Business School: MBA Program versus Research Performance. Academy of Management Journal v43 n6 (2000): p. 1130-1141.

29. US News \& World Report. America's best graduate schools. Washington, DC : U.S. News \& World Report, 1998- (Annual Publication).

30. Webster, David S. Academic Rankings: First on a List of One. Academe. v78 n5 (Sept-Oct 1992): p.19-22.

31. Wright, B. Ann. A Little Learning Is a Dangerous Thing: A Look at Two Popular College Rankings. College Board Review. n163 (Spr 1992): p.6-16.

\section{NOTES}

